\title{
PERBANDINGAN MOTIVASI BELAJAR SISWA KELAS V SD X, Y, Z BERDASARKAN JENIS KELAMIN DAN PARTISIPASI BIMBINGAN BELAJAR
}

\author{
Kelly Santana ${ }^{1}$, Fransisca I. R. Dewi ${ }^{2}$, dan Yohanes Budiarto ${ }^{3}$ \\ ${ }^{1}$ Fakultas Psikologi Pendidikan, Universitas Tarumanagara Jakarta \\ Email:kelly.santana.11@gmail.com \\ ${ }^{2}$ Fakultas Psikologi, Universitas Tarumanagara Jakarta \\ Email: fransiscar@fpsi.untar.ac.id \\ ${ }^{3}$ Fakultas Psikologi, Universitas Tarumanagara Jakarta \\ Email: yohanesb@fpsi.untar.ac.id
}

\begin{abstract}
ABSTRAK
Dalam masyarakat Indonesia, hampir tiga dekade, kursus bimbinan belajar menjadi bagian dari proses belajar, selain sekolah formal. Orang tua mengikutsertakan anaknya dalam bimbingan belajar dengan tujuan supaya prestasi belajar anak menjadi lebih baik. Prestasi belajar merupakan salah satu indikator dari motivasi belajar. Motivasi belajar merupakan prediktor signifikan dari prestasi belajar. Motivasi belajar dibedakan menjadi tiga, yaitu motivasi intrinsik, motivasi ekstrinsik, dan amotivasi. Tujuan penelitian ini untuk menguji perbedaan motivasi belajar siswa berdasarkan jenis kelamin dan partisipasi bimbingan belajar. Partisipan adalah 157 siswa kelas 5 dari tiga sekolah dasar di Jakarta, berusia antara 9-12 tahun. Instrumen penelitian berupa kuesioner motivasi belajar. Setelah melalui uji validitas dan reliabilitas, diperoleh Cronbach's alpha sebesar 0.727. Hasil penelitian menunjukkan bahwa siswa memiliki motivasi belajar yang tinggi. Analisis data menggunakan Independent-Samples $T$ Test menunjukkan bahwa terdapat perbedaan motivasi belajar berdasarkan jenis kelamin, $t(155)=2,137$, $p<0.05$. Demikian pula terdapat perbedaan motivasi belajar berdasarkan partispasi bimbingan belajar, $t(155)=$ $2.058, p<0.05$.
\end{abstract}

Kata kunci: motivasi belajar, sekolah dasar, partisipasi bimbingan belajar

\section{PENDAHULUAN}

\section{Latar Belakang}

Di abad ke-21, sejak tiga dekade, jumlah kursus atau bimbingan belajar semakin banyak karena diminati para orangtua. Orangtua mengikutsertakan anaknya dalam berbagai kursus atau bimbingan belajar. Adapun orangtua memiliki tujuan supaya prestasi belajar anaknya yang lebih baik ("Sukses Dengan Usaha Bimbingan Belajar Rumahan", 2015). Prestasi belajar merupakan salah satu indikator motivasi belajar (Schunk, Pintrich, \& Meece 2008; Singh \& Singh, 2013). Pernyataan tersebut didukung oleh temuan penelitian Ning dan Downing (dalam Yau, Kan, \& Cheng, 2011), bahwa motivasi belajar merupakan prediktor prestasi belajar yang paling penting. Menurut Tucker, Zayco, dan Herman (dalam Singh \& Singh, 2013), faktor-faktor yang lain dapat mempengaruhi prestasi belajar hanya dengan memberikan efek terhadap motivasi belajar terlebih dahulu.

Faktor yang memengaruhi prestasi belajar anak, meliputi faktor intrinsik dan ekstrinsik. Faktor intrinsik berasal dari dalam diri anak, antara lain: inteligensi, motivasi, sikap, minat, bakat, dan konsentrasi. Sementara itu, faktor ekstrinsik berasal dari luar diri anak, antara lain: keluarga, faktor sekolah, dan faktor masyarakat (Simanjuntak, 2013). 
Berdasarkan beberapa kajian dan kondisi di lapangan, penulis berasumsi siswa yang mempunyai motivasi belajar tinggi akan mendapatkan nilai yang lebih maksimal daripada anak yang tidak termotivasi. Penulis melakukan penelitian ini untuk mengetahui perbandingan motivasi belajar siswa ditinjau dari jenis kelamin dan partisipasi siswa dalam partisipasi bimbingan belajar.

\section{Rumusan Masalah}

Rumusan masalah pada penelitian ini, yaitu apakah terdapat perbedaan motivasi belajar siswa kelas V sekolah dasar X, Y, Z berdasarkan jenis kelamin dan partisipasi bimbingan belajar.

\section{Motivasi Belajar}

Berdasarkan self-determination theory (SDT), motivasi adalah "the reasons that underlie behavior" (Ryan \& Deci dalam Guay et al., 2010). Menurut McClelland (dalam Takeuchi et al., 2014), motivasi belajar adalah "a recurrent need to improve one's past performance". Sedangkan, Kurasawa (dalam Takeuchi et al., 2014) mendefinisikan motivasi belajar sebagai "the desire to handle difficult tasks and succeed in them".

Dalam dunia pendidikan, motivasi belajar didefinisikan sebagai "reasons that students engage in different school activities" (Ryan \& Deci dalam Guay et al., 2010). Selain kedua definisi tersebut, motivasi belajar juga diartikan sebagai "enjoyment of school learning characterized by a mastery orientation, curiosity, persistence, task-endogeny, and the learning of challenging, difficult, and novel tasks" (Gottfried dalam Paul, Subalukshmi, \& Mala, 2014).

Jadi, motivasi belajar adalah alasan yang membuat seorang anak mau terlibat dalam proses pembelajaran, serta mau berusaha dan berhasil dalam mengatasi kesulitan-kesulitan. Terdapat tiga tipe motivasi akademik, yaitu motivasi intrinsik, motivasi ekstrinsik, dan amotivasi (Deci \& Ryan, 2000). Dalam self-determination continuum (Deci \& Ryan, 2000), rentang sebelah kanan menunjukkan self-determined behavior sedangkan rentang sebelah kiri menunjukkan non selfdetermined behavior. Motivasi intrinsik berada pada rentang paling kanan, motivasi ekstrinsik berada pada rentang tengah, dan amotivasi berada pada rentang paling kiri (Deci \& Ryan, 2000).

\section{Motivasi Intrinsik}

Motivasi intrinsik didefinisikan sebagai "participation in an activity or completion of a task out of curiosity or a desire to learn, engaging in the activity or completing a task for the sake of doing it or with a willingness to contribute" (Deci; Gottfried; Bates; Deci, Vallerand, Pelletier, \& Ryan; Mills dalam Rivers, 2008). Sebuah tindakan yang didasarkan pada motivasi intrinsik mempunyai tujuan untuk mendapatkan kesenangan dan kepuasan diri, serta dilakukan secara sukarela (Deci, Vallerand, Pelletier, \& Ryan; Vallerand \& Bissonnette; Vallerand, et al;dalam Paul et al., 2014). Satu contoh dari motivasi intrinsik, ialah kesenangan yang dirasakan seorang siswa ketika ia mempelajari hal yang baru (Singh \& Singh, 2013).

Berdasarkan beberapa hasil penelitian terdahulu, motivasi intrinsik berhubungan dengan kualitas pembelajaran yang lebih baik (Fortier, Vallerand, \& Guay dalam Singh \& Singh, 2013), performa akademik yang positif (Deci et al. dalam Singh \& Singh, 2013), dan prestasi akademik yang lebih tinggi (Soenens \& Vansteenkiste dalam Singh \& Singh, 2013). Pernyataan tersebut juga sesuai dengan hasil studi lain yang menyatakan bahwa motivasi intrinsik pada siswa remaja dapat mendukung hasil prestasi belajar yang lebih tinggi dan membantu para siswa untuk mencapai kesuksesan (Adelman; Gottfried dalam Rivers, 2008). Jadi kesimpulannya, yaitu hubungan antara motivasi intrinsik dan prestasi belajar siswa sangat kuat (Gottfried; Adelman; 
Adelman \& Taylor dalam Rivers, 2008) dan motivasi intrinsik memiliki kontribusi terhadap performa sekolah yang baik (Gottfried et al. dalam Areepattamannil, Freeman, Klinger, 2011).

\section{Motivasi Ekstrinsik}

Motivasi ekstrinsik adalah "participation in an activity or completion of a task due to external incentives, which may include attaining a reward or avoiding punishment" (Adelman \& Taylor; Ball; Beck; Deci; Wiersma dalam Rivers, 2008). Satu contoh dari motivasi ekstrinsik ialah ketika seseorang melakukan sesuatu karena perilaku tersebut dihargai oleh orang lain (Ryan \& Deci dalam Singh \& Singh, 2013). Menurut teori self-determination (SDT), terdapat empat tipe motivasi ekstrinsik (Guay et al., 2010; Ryan \& Deci dalam Areepattamannil et al., 2011). Berikut ini merupakan tipe-tipe motivasi ekstrinsik, dari tingkat self-determination yang paling rendah hingga yang paling tinggi (Ryan \& Deci dalam Guay et al., 2010): (1) external regulation, (2) introjected regulation, (3) identified regulation, dan (4) integrated regulation.

External regulation terjadi ketika seseorang melakukan sesuatu karena dimotivasi oleh keinginan untuk mendapatkan imbalan atau menghindari hukuman eksternal (Guay et al., 2010; Areepattamannil et al., 2011; Paul et al., 2014). Introjected regulation terjadi ketika suatu tindakan dilakukan karena adanya tekanan internal, misalnya kewajiban, perasaan bersalah, atau rasa malu (Guay et al., 2010; Areepattamannil et al., 2011). Identified regulation terjadi ketika suatu perilaku dilakukan karena perilaku tersebut merupakan hal yang penting bagi mereka secara pribadi (Guay et al., 2010; Areepattamannil et al., 2011), yang mana tidak ada tekanan eksternal ketika seseorang melakukan tindakan tersebut (Fortier et al. dalam Paul et al., 2014). Sedangkan, integrated regulation terjadi ketika seseorang melakukan suatu tindakan karena tindakan tersebut merupakan bagian dari siapa dirinya dan sesuai dengan nilai-nilai serta kebutuhan dirinya (Deci, Ryan, \& Williams dalam Guay et al., 2010). Menurut Harter (dalam Guay et al., 2010), integrated regulation dapat berkembang hanya pada akhir masa remaja atau pada awal masa dewasa.

Motivasi ekstrinsik juga dikelompokkan menjadi dua bentuk berdasarkan self-determination theory, yaitu non self-determined extrinsic motivation dan self-determined extrinsic motivation (Gillet, Vallerand, \& Lafrenière, 2012). Non self-determined extrinsic motivation merupakan motivasi ektrinsik yang terkontrol, dimana seseorang melakukan sesuatu karena adanya tekanan (Deci \& Ryan, 2000). Self-determined extrinsic motivation merupakan motivasi ekstrinsik yang tidak terkontrol, dimana seseorang melakukan sesuatu sepenuhnya karena kehendak pribadi (Deci \& Ryan, 2000). Tipe motivasi ekstrinsik external regulation dan introjected regulation termasuk dalam kelompok non self-determined extrinsic motivation (Deci \& Ryan, 2000). Sedangkan tipe motivasi ekstrinsik identified regulation dan integrated regulation termasuk dalam kelompok self-determined extrinsic motivation (Deci \& Ryan, 2000).

Sama seperti motivasi intrinsik, motivasi ekstrinsik juga berkorelasi dengan performa sekolah. Contohnya ialah siswa yang mempunyai motivasi intrinsik dan motivasi ekstrinsik tipe identified regulation biasanya lebih gigih dalam menyelesaikan tugas sekolah, mengalami lebih banyak emosi positif, dan memperoleh nilai yang lebih baik (Guay et al., 2010). Namun, motivasi ekstrinsik juga dapat memberikan dampak yang negatif, misalnya kecemasan yang lebih besar dan kemampuan untuk mengatasi kesulitan yang kurang baik (Deci \& Ryan dalam Singh \& Singh, 2013). Siswa yang melakukan suatu tindakan hanya karena adanya imbalan eksternal atau untuk menghindari hukuman (external regulation) akan mengganggu motivasi intrinsik dan dapat memberikan hasil pencapaian belajar yang lebih rendah (Gottfried, Fleming, \& Gottfried dalam Rivers, 2008). Insentif eksternal atau hukuman yang digunakan untuk mengontrol suatu perilaku dianggap sebagai sebuah tekanan bagi siswa (Deci \& Ryan dalam Rivers, 2008), yang 
pada akhirnya akan mengakibatkan self-determination (faktor yang mempengaruhi motivasi intrinsik) menjadi terbatasi (Adelman \& Taylor; Harackiewicz dalam Rivers, 2008).

\section{Amotivasi}

Amotivasi ialah tipe terakhir dari motivasi. Amotivasi didefinisikan sebagai "the state of lacking intention to act" (Singh \& Singh, 2013). Di saat seseorang tidak termotivasi, orang tersebut tidak akan melakukan apapun, atau mereka melakukan tindakan tetapi tanpa adanya keinginan atau niat sama sekali. Menurut Vallerand et al. (dalam Singh \& Singh, 2013), individu yang terdemotivasi percaya bahwa hasil dari suatu tindakan tidak berada di bawah kendali mereka. Hal ini juga sesuai dengan pernyataan yang dikemukakan oleh Deci dan Ryan (dalam Paul et al., 2014) bahwa seseorang yang terdemotivasi tidak melihat adanya hubungan antara perilaku mereka dengan hasil dari perilaku tersebut, mereka percaya bahwa perilaku mereka bukanlah sesuatu yang dapat mereka kontrol. Menurut Fortier dan rekan-rekannya, amotivasi dapat memberikan dampak negatif terhadap pendidikan (dalam Paul et al., 2014).

\section{METODE PENELITIAN \\ Partisipan}

Total partisipan berjumlah 157 siswa kelas 5 SD dari tiga sekolah, yaitu SD X, SD Y, dan SD Z. Ketiga sekolah merupakan sekolah nasional yang berlokasi di Jakarta. Terdapat 86 siswa lakilaki (54.8\%) dan 71 siswa perempuan (45.2\%). Usia partisipan berkisar 9-12 tahun dengan rincian sebagai berikut: usia 9 tahun berjumlah 32 siswa (20.4\%), 10 tahun berjumlah 83 siswa (52.9\%), 11 tahun berjumlah 40 siswa (25.5\%), dan 12 tahun berjumlah 2 siswa (1.3\%). Selain itu, terdapat 137 siswa yang berpartisipasi dalam bimbingan belajar (87.3\%) dan 20 siswa yang tidak berpartisipasi dalam bimbingan belajar (12.7\%).

\section{Prosedur dan Alat Ukur}

Prosedur dalam pengumpulan data digambarkan sebagai berikut: siswa mengisi kuesioner yang mengukur motivasi belajar yang dibagikan di kelas pada ketiga sekolah yang bersedia menjadi lokasi penelitian ini. Pengumpulan data berlangsung dari bulan Juni hingga bulan September. Pada bulan Juni 2017, pengambilan data dilakukan di SD X. Kemudian pada akhir bulan Juli 2017 sampai awal Agustus 2017, pengambilan data dilakukan di SD Y. Terakhir pada bulan September 2017, pengambilan data dilakukan di SD Z. Pengerjaan kuesioner dilakukan secara individu oleh para siswa. Kuesioner disusun dengan dengan menggunakan bahasa Indonesia.

\section{Motivasi Belajar}

Alat ukur motivasi belajar diterjemahkan berdasarkan alat ukur Gillet et al. (2012). Terdapat empat dimensi yang diukur dalam alat ukur motivasi belajar ini, yaitu: (1) intrinsic motivation terdiri dari 3 item ("Aku senang mengerjakan PR."); (2) self-determined extrinsic motivation terdiri dari 3 item ("Aku memilih untuk mengerjakan PR meskipun tidak ada yang memintaku untuk mengerjakan PR."); (3) non self-determined extrinsic motivation terdiri dari 3 item ("Kalau aku tidak mengerjakan PR, mama akan memarahiku."); dan (4) amotivation terdiri dari 3 item ("Aku tidak tahu alasannya mengapa aku harus mengerjakan PR."). Total item dalam alat ukur ini berjumlah 12 item. Alat ukur motivasi belajar terdiri atas tiga jenis aktivitas: (1) mengerjakan pekerjaan rumah (PR), (2) memperhatikan guru mengajar, dan (3) pergi ke sekolah. Skala penilaian menggunakan 5-poin skala Likert dimana angka 1 menunjukkan bahwa partisipan sangat tidak setuju dengan pernyataan, angka 2 menunjukkan bahwa partisipan tidak setuju dengan pernyataan, angka 3 menunjukkan bahwa partisipan netral dengan pernyataan, 
angka 4 menunjukkan bahwa partisipan setuju dengan pernyataan, dan angka 5 menunjukkan bahwa partisipan sangat setuju dengan pernyataan.

\section{Validitas Alat Ukur Motivasi Belajar}

Dalam penelitian ini, pengujian validitas dilakukan dengan menggunakan face validity yang menunjukkan bahwa peneliti harus menjelaskan arti dari kata "Netral" pada pilihan skala. Sebelumnya, peneliti juga telah melakukan content validity, melalui expert judgement dengan dua pembimbing penelitian.

\section{Reliabilitas Alat Ukur Motivasi Belajar}

Pada penelitian ini, hasil pengujian reliabilitas menunjukkan hasil akhir angka cronbach's alpha yang didapatkan ialah sebesar 0.727 dimana terdapat 1 butir yang harus dibuang karena memiliki nilai korelasi di bawah 0.2 , yaitu butir ke-11 ("Kalau aku tidak pergi ke sekolah, orangtua akan memarahiku"). Hasil angka cronbach's alpha ini menunjukkan bahwa alat ukur ini reliabel.

\section{HASIL DAN PEMBAHASAN}

Hasil penelitian menunjukkan bahwa motivasi belajar yang dimiliki siswa kelas 5 SD di sekolah $\mathrm{X}, \mathrm{Y}, \mathrm{Z}$ termasuk tinggi. Hal tersebut digambarkan dari nilai rata-rata motivasi belajar siswa (M $=3,7452)$ lebih tinggi daripada nilai median $(\mathrm{Med}=3)$. Selain itu, hasil descriptive statistics menunjukkan bahwa motivasi belajar siswa memiliki nilai minimum 1.82, nilai maximum 5.00, dan standar deviasi 0.56 .

Perbedaan motivasi belajar berdasarkan jenis kelamin, diuji melalui Independent-Samples T Test, memberikan hasil bahwa terdapat perbedaan motivasi belajar berdasarkan jenis kelamin, motivasi belajar siswa perempuan $(\mathrm{M}=3.85, \mathrm{SD}=0.487)$ lebih tinggi daripada motivasi belajar siswa laki-laki $(\mathrm{M}=3.66, \mathrm{SD}=0.612) ; \mathrm{t}(155)=2,137, \mathrm{p}<0.05$.

Perbedaan motivasi belajar berdasarkan partisipasi dalam bimbingan belajar, diuji melalui Independent-Samples $T$ Test, memberikan hasil bahwa terdapat perbedaan motivasi belajar berdasarkan partisipasi bimbingan belajar, motivasi belajar siswa yang berpartisipasi dalam bimbingan belajar $(\mathrm{M}=3.78, \mathrm{SD}=0.578)$ lebih tinggi daripada motivasi belajar siswa yang tidak berpartisipasi dalam bimbingan belajar $(\mathrm{M}=3.50, \mathrm{SD}=0.403) ; \mathrm{t}(155)=2.058, \mathrm{p}<0.05$.

\section{Pembahasan}

Hasil penelitian menunjukkan motivasi belajar siswa yang tinggi. Motivasi berlajar tersebut dapat dipengaruhi oleh beberapa faktor eksternal. Didukung penelitian Schunk et al(2008) bahwa rekan sebaya (peers), keluarga, guru, serta kelas dan sekolah. Rekan sebaya dapat mempengaruhi motivasi belajar siswa melalui proses observasi via pemodelan (Schunk et al., 2008). Keluarga dapat mempengaruhi motivasi belajar siswa melalui pola asuh orangtua dan keterlibatan orangtua dalam pendidikan anak (Schunk et al., 2008). Guru juga memiliki peran motivasi belajar siswa, misalnya melalui pemberian penghargaan atas kinerja siswa yang baik dalam pembelajaran dan strategi pengajuan pertanyaan (Schunk et al., 2008). Kelas dan sekolah dapat mempengaruhi motivasi belajar siswa, misalnya melalui pengorganisasian kelas dan iklim budaya sekolah (Schunk et al., 2008).

Hasil penetian yang dilakukan pada siswa sekolah dasar menujukkan bahwa motivasi belajar siswa perempuan lebih tinggi daripada motivasi belajar siswa laki-laki. Hal ini tidak sejalan dengan Liu dan Zhu (dalam Maheswari \& Aruna, 2016) bahwa siswa laki-laki memiliki motivasi belajar yang lebih tinggi daripada siswa perempuan pada tingkat sekolah menengah atas. 
Penelitian lain di bidang musik menunjukkan bahwa murid perempuan mempunyai motivasi intrinsik yang lebih tinggi daripada murid laki-laki (Schatt dalam Yau et al., 2011). Sementara itu, penelitian yang dilakukan oleh Shang (dalam Yau et al., 2011) memberikan hasil bahwa siswa perempuan mempunyai motivasi intrinsik yang lebih rendah daripada siswa laki-laki pada pendidikan olahraga. Akan tetapi, hasil yang berbeda ditunjukkan oleh Nagarathanamma dan Rao (dalam Maheswari \& Aruna, 2016) yang menyatakan bahwa tidak ada perbedaan motivasi belajar yang signifikan di antara siswa laki-laki dan siswa perempuan.

Selain itu, ada penelitian yang menyatakan bahwa motivasi belajar siswa laki-laki lebih tinggi daripada motivasi belajar siswa perempuan dalam pelajaran matematika (Schunk et al., 2008). Akan tetapi, belum ada studi yang meneliti motivasi belajar secara keseluruhan (dari semua mata pelajaran) berdasarkan jenis kelamin (Schunk et al., 2008).

Dikaitkan dengan partisipasi bimbingan belajar, terdapat perbedaan motivasi belajar antara yang mengikuti partisipasi bimbingan belajar dengan yang tidak. Hal ini sesuai temuan Stocklmayer et al;Coll et al; RSC (dalam Affeldt et al., 2017) bahwa pendidikan non formal mempunyai beberapa manfaat, di antaranya yaitu, meningkatkan motivasi belajar dan minat siswa terhadap bidang sains, serta membantu mengarahkan siswa terkait karir yang berhubungan dengan sains.

Terdapat kekurangan dalam penelitian ini. Sampel partisipan dalam penelitian ini hanya dari siswa kelas V dari tiga sekolah saja. Maka dari itu, hasil penelitian ini belum tentu bisa digeneralisasi ke seluruh siswa sekolah dasar.

\section{KESIMPULAN DAN SARAN}

Penelitian ini memberikan beberapa temuan, yaitu: (1) motivasi belajar siswa kelas 5 di SD X, Y, dan $\mathrm{Z}$ termasuk tinggi; (2) terdapat perbedaan motivasi belajar berdasarkan jenis kelamin, motivasi belajar siswa perempuan lebih tinggi daripada motivasi belajar siswa laki-laki; dan (3) terdapat perbedaan motivasi belajar berdasarkan partisipasi bimbingan belajar, motivasi belajar siswa yang berpartisipasi dalam bimbingan belajar lebih tinggi daripada siswa yang tidak berpartisipasi dalam bimbingan belajar.

Saran untuk penelitian selanjutnya, yaitu memperluas jangkauan partisipan. Partisipan dapat mencakup tidak hanya siswa dari tingkat sekolah dasar, tetapi juga siswa dari tingkat sekolah menengah. Selain itu, partisipan juga dapat dibedakan berdasarkan etnis dan status sosioekonominya untuk meneliti apakah ada perbedaan motivasi belajar berdasarkan etnis dan status sosio-ekonomi. Penelitian selanjutnya juga dapat melakukan kajian motivasi belajar yang dikaitkan dengan dukungan teman sebaya atau dukungan keluarga.

\section{Ucapan Terima Kasih}

Penulis mengucapkan terima kasih kepada para partisipan penelitian yang telah membantu proses pengumpulan data dalam penelitian ini. Penulis juga mengucapkan terima kasih kepada para guru dan kepala sekolah yang telah memberikan kesempatan kepada penulis untuk melakukan penelitian di sekolah tersebut. Dengan bantuan dari para partisipan, guru, dan kepala sekolah maka penulis dapat menyelesaikan penelitian ini. 


\section{REFERENSI}

Affeldt, F., Tolppanen, S., Akselab, M., \& Eilks, I. (2017). The potential of the non-formal educational sector for supporting chemistry learning and sustainability education for all students - A joint perspective from two cases in Finland and Germany. The Royal Society of Chemistry: Chemistry Education Research and Practice, 18, 13-25. doi: 10.1039/c6rp00212a

Areepattamannil, S., Freeman, J. G., Klinger, D. A. (2011). Intrinsic motivation, extrinsic motivation, and academic achievement among Indian adolescents in Canada and India. Soc Psychol Educ, 14, 427-439. doi: 10.1007/s11218-011-9155-1

Deci, E. L., \& Ryan, R. M. (2000). The "what" and "why" of goal pursuits: Human needs and the self-determination of behavior. Psychological Inquiry, 11(4), 227-268.

Garner, N., \& Eilks, I. (2015). The expectations of teachers and students who visit a non-formal student chemistry laboratory. Eurasia Journal of Mathematics, Science \& Technology Education, 11(5), 1197-1210.

Gillet, N., Vallerand, R. J., \& Lafrenière, Marc-André. K. (2012). Intrinsic and extrinsic school motivation as a function of age: The mediating role of autonomy support. Soc Psychol Educ, 15, 77-95. doi: 10.1007/s11218-011-9170-2

Guay et al. (2010). Intrinsic, identified, and controlled types of motivation for school subjects in young elementary school children. British Journal of Educational Psychology, 80, 711735. doi: 10.1348/000709910X499084

Maheswari, K. K., \& Aruna, M. (2016). Gender difference and achievement motivation among adolescent school students. International Journal of Applied Research, 2(1), 149-152.

Paul, H., Subalukshmi, S. S. S, \& Mala, V. (2014). Resilience, academic motivation and social support among college students. Indian Journal of Positive Psychology, 5(4), 430-434.

Rivers, J. (2008). The relationship between parenting style and academic achievement and the mediating influences of motivation, goal-orientation and academic self-efficacy (Doctoral dissertation). Available from Florida State University Libraries Electronic Theses, Treatises and Dissertations.

Schunk, D. H., Pintrich, P. R., \& Meece, J. L. (2008). Motivasi dalam pendidikan: Teori, penelitian, dan aplikasi (3rd ed.). New Jersey, NJ: Pearson Education.

Simanjuntak, W. (2013). Faktor-faktor yang mempengaruhi prestasi belajar. Kompasiana. Diambil 31 Oktober 2016 dari http://www.kompasiana.com/wantisimanjuntak/faktorfaktor-yang-mempengaruhi-prestasi-belajar_552e34eb6ea83482208b456d

Singh, P., \& Singh, N. (2013). Difficulties in emotion regulation: A barrier to academic motivation and performance. Journal of the Indian Academy of Applied Psychology, 39(2), 289-297.

Sukses dengan usaha bimbingan belajar rumahan. (2015). Diambil 18 Desember 2016 dari http://infoloka.com/sukses-dengan-usaha-bimbingan-belajar-rumahan/

Takeuchi, H. et al. (2014). Regional gray matter density is associated with achievement motivation: Evidence from voxel-based morphometry. Brain Struct Funct, 219, 71-83. doi: 10.1007/s00429-012-0485-3

Yau, H. K., Kan, M. S., \& Cheng, A. L. F. (2011). Gender differences on intrinsic motivation in Hong Kong higher education. Organizational Learning and Leadership, 9(2), 63-80. 